\title{
INNOVATIVE METHODS AND APPROACHES TOWARDS THE DEVELOPMENT OF THE STUDENTS' ENTREPRENEURIAL COMPETENCIES
}

\author{
Aistė Ragauskaitė, Jurgita Zaleckienė \\ Aleksandras Stulginskis University, Lithuania \\ aiste.ragauskaite@asu.lt; jurgita.zaleckiene@asu.lt
}

\begin{abstract}
In educational strategy papers, it is determined that entrepreneurial development should be implemented already in schools. Various methods and approaches can be used for the development. The majority of entrepreneurial competences are developed at the university - subjects devoted to the development of entrepreneurship are included in the study programs. Environment of the university is very friendly to this - not only because of activities devoted to entrepreneurship occurring in the academic environment, plenty seminars and trainings, but also because of the students' personal maturity and motivation. Scholars actively raise the following questions: how to develop entrepreneurial competences effectively? Which methods are the most applicable? What kind of innovative methods are the most necessary? 104 students, who tried simulation traineeship of entrepreneurial development, were questioned in order to analyze the impact of methods and the change in entrepreneurial competences. The research was carried out in the Faculty of Economics and Management of Aleksandras Stulginskis University. The participants of the research were involved in the business simulation, where they had an opportunity to estimate themselves and improve their backgrounds, abilities and skills. Methods promoting and developing creativity were applied in simulation business enterprises; however, not all methods had worked. The methods of graphic representation were used by the minority and they were not considered to be very effective. The aim of the research was to determine entrepreneurial competences and innovative educational methods theoretically and to test empirically the development of entrepreneurial competences via simulation method.
\end{abstract}

Key words: methods of innovative education, entrepreneurial competences.

\section{Introduction}

Many scholars search and analyze entrepreneurial competences and educational methods. However, this is still a relevant subject to scientific analysis due to the fast changing person whose competences are being developed. The main problem of all systems is that the person has to estimate his entrepreneurial competences on his own - there is no system, which would help to develop a portfolio of entrepreneurial competences.

The aim of the research was to determine entrepreneurial competences and innovative educational methods theoretically and to test empirically the development of entrepreneurial competences via simulation method.

In some cases (Robles, Zárraga-Rodríguez, 2015), there is an aim to determine the essential entrepreneurial competences; however, the researchers follow the holistic approach - entrepreneurial competences are combined and integrated sets of person's knowledge, skills, views, personality and motivation (Driesen \& Zwart, 1999; Kyndt, Baert, 2015; Lans, 2014; Schachter et al., 2015), which create the potential for the entrepreneurship.

Scholars (Schachter et al., 2015; Estrin et al., 2014; Schelfhout et al., 2016; Ismail et al., 2015; Lans et al., 2014; Donnellon et al., 2014; Driessen \& Zwart, 1999) present different and individual sets of characteristic features, which, in general, can be identified as entrepreneurial competences of entrepreneurial person (Figure 1). Entrepreneurial competences are very individual - if the person has entrepreneurial competences, it does not mean that he will become a businessman. This is caused by many objective and subjective factors, external business environment conditions (Stamboul et al., 2014). It is often an open question - whether entrepreneurial competences are inherited or gained? However, it is recognized (Garalis \& Stazdienè, 2006) that the level of entrepreneurship and motivation will be higher in that case if entrepreneurial competences are developed. The scholars agree that experience influences person's entrepreneurship significantly; however, dynamic business environment causes the fact that gained knowledge and abilities have to be developed constantly. Development of entrepreneurial competences include knowledge transfer, development of skills and formation of personality. According to Henry (2005) et al., it is very important to develop students' entrepreneurship in the environment close to real business.

Mueller \& Anderson (2014) state that the problem of the development of entrepreneurial competences is the fact that entrepreneurial competences are integrated and complex objects; therefore, simple methods are not enough for the development of these competences. According to Jansen (2015), it is necessary to create the whole "ecosystem" of the development of entrepreneurship, which includes lectures, business orders, practices, meetings with successful businessmen, instruments for financial support, etc. The education of entrepreneurial competences is only a tool helping to prepare, improve skills and knowledge. Also, it is often highlighted that 


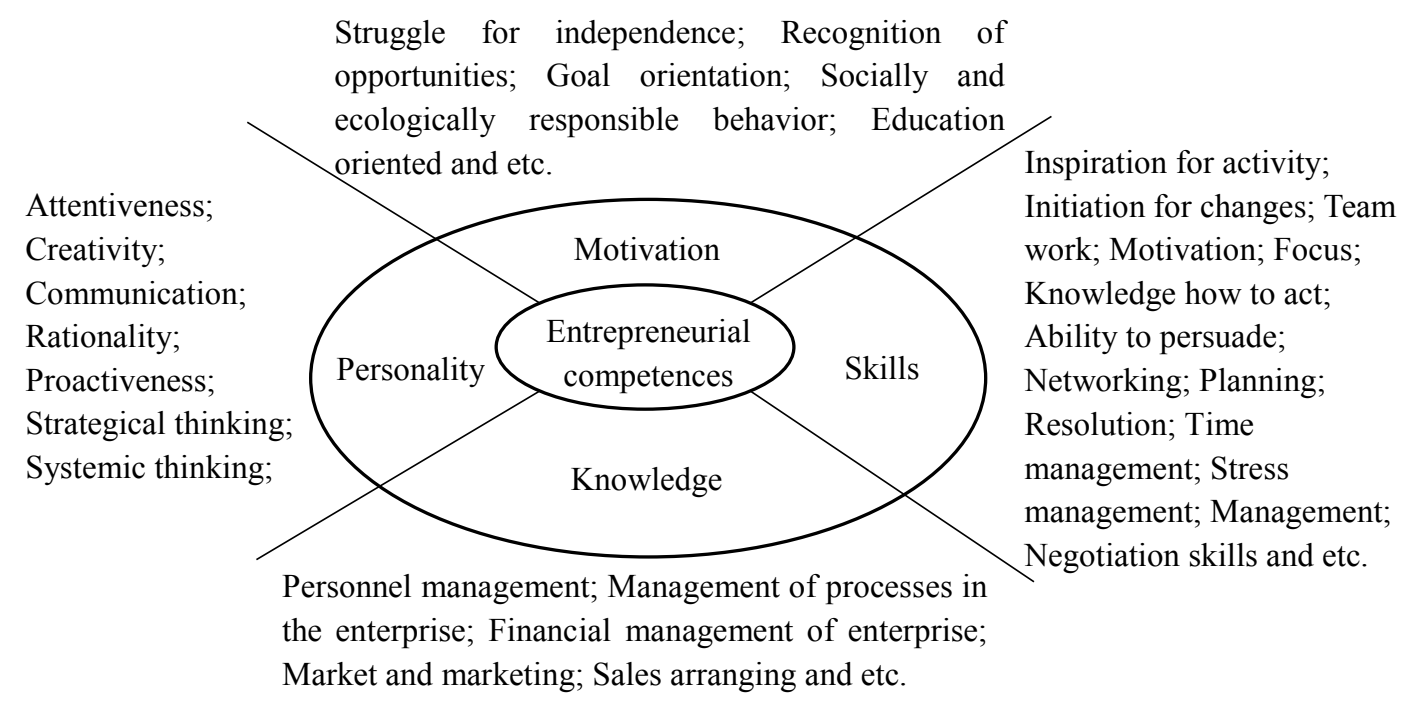

Source: developed by Schachter et al., 2015; Estrin et al., 2014.

Figure 1. Structure of entrepreneurial competences.

methods driving creativity are very necessary for the education of entrepreneurship.

Consequently, it can be stated that education of entrepreneurial competences is a dynamic process, where methods and other measures used for the education of entrepreneurial competences should be updated regularly. Methods can be divided into provided methods, for instance, methods driving creativity, resolution, and methods simulating real situations and this particular method is adapted in studies of management from medical studies. The majority of scholars has the opinion that students do better when active simulation methods are included in learning process. This is due to the fact that simulation method helps to try activities in safe environment and students are not to be afraid of results and mistakes (Hyun \& Kim, 2015; Shin et al., 2015). According to Walters et al., (2017) a simulation method improves participants' knowledge, increases motivation and improves competences. Simulation is applied effectively in medicine and this adapted method can be used in management studies, when simulation business enterprises have been developed. Meanwhile simulation has been connected to the theory of experiential learning and the so-called game method is used to achieve the desired results (Guardia et al., 2014).

In order to develop entrepreneurial competences, the following four dimensions should be developed: creative thinking, graphic thinking, provocation creative technique and resultative thinking. These dimensions can be improved while applying various methods, which in one or another way contribute to the development of each personal entrepreneurial competence. The educational simulation method of entrepreneurial competence has to be composed of mentioned four dimensions:

Creative thinking (the following entrepreneurial competences are developed: attentiveness, creativity, communication, rationality, pro-activeness, strategical thinking, systemic thinking).

Applied method-Lotus flower. The most important thing in this method is to ensure that students would not lose the main idea - all other ideas should complement the idea which is in the center of lotus flower. At the very beginning the main idea, problem, question or situation is written in lotus center. In the second stage 8 petals are drawn and each petal is filled with solution related to the issue (Misiukonis et al., 2015).

Applied method-SCAMMPERR. This is a method, which promotes the generation of new ideas within several elements. $\mathrm{S}$ - substitute (possible alternatives), $\mathrm{C}$ - combine (to blend, combine, mix, learn to use one instead of another), $\mathrm{A}$ - adapt (adaptation is more complicated process than general linking. In this case, we change the general functions of linked elements), $\mathrm{M}$ - magnify (to maximize, boost), $\mathrm{M}$ - modify (to modify, change), $\mathrm{P}$ - put (to find another way to use a product), $\mathrm{E}$ - eliminate (to remove, delete), $\mathrm{R}$ rearrange (to change the order), $\mathrm{R}$ - reverse (to turn everything upside down). This method can be used all day in that case if students perform every action consistently while discussing and working out final solutions (Buzys, 2016).

Graphic thinking (the following entrepreneurial competences are developed: inspiration for activity, initiation for changes, teamwork, motivation, focus, knowledge how to act, ability to persuade, networking, planning, etc.)

Applied method - Visualization. This method is appropriate for discussion of results and expression 
of opinion. Students can be asked to draw or work with a colleague. Also, they can be asked to search relevant examples of solutions on the Internet, group and schematize findings and provide suggestions. This method can encourage students to provide suggestions in a creative and non-standard manner. In addition, the program canva.com can be suggested to the students as a tool for visualization. This program is free and every user can use various designs, present collected information in an interesting way and learn new ways of creation on their own.

Provocation creative technique (the following entrepreneurial competences are developed: struggle for independence, recognition of opportunities, customer orientation, goal orientation, socially and ecologically responsible behavior, education oriented, etc.)

Applied method - World café. This method is useful when there is a need to share information, create informal dialogue and relation, provoke bigger discussion with large groups, solve complicated, difficult questions and find solutions, to promote person's responsibility for the results. Participants sit by the tables and discuss about suggested topic, identify the main ideas and share them with other participants sitting by other tables (Misiukonis et al., 2015).

Resultative thinking (the following entrepreneurial competences are developed: personnel management; management of the processes in enterprise, financial management, market and marketing)

Applied method - Diary. This method is applied in all stages of the process. Participants in advance are asked to identify all their feelings, questions, contradictions, joys and failures. It is very important to start a diary from the first stage of the process in order to form a habit of filling the diary. The diary should be anonymous and not discussed publicly - it goes to enterprise as a written document and becomes an additional source of information about the improvement of the possible involvement process (Buzys, 2016).

A combination of selected entrepreneurial competences has to be applied to each dimension and the developed combination should be promoted during methods selected to each stage of thinking. Modern students change very rapidly; thus, it is important to search innovative educational systems constantly and to evaluate the achieved result, for example, personal portfolio of entrepreneurial competences.

\section{Materials and Methods}

While organizing and performing empirical research the systematical framework was followed - in order to solve problems, to learn about phenomenon, it is necessary to apply various quantitative and qualitative research methods (Žydžiūnatè, 2017;
Kardelis, 2016). In this case, qualitative research was compiled with quantitative research.

The aim of the empirical research was to determine the importance of innovative educational methods in the field of the development of students' entrepreneurial competences.

In order to perform empirical research, a method of case analysis was chosen. Simulation practice of education of entrepreneurship in the Faculty of Economics and Management in Aleksandras Stulginskis University was chosen as case for analysis. In order to collect necessary data, methods of document analysis and surveys were applied. Principles of simulation development of entrepreneurship were identified after the document analysis. In order to evaluate the importance of this practice in developing students' entrepreneurial competences, a survey was carried out. 104 students, who had this traineeship in the spring semester in 2017, were surveyed. Authors of the article performed a role of consultants during the traineeship. They took into consideration their insights and opinions while analyzing received results of survey.

A questionnaire was composed of several blocks of questions. Firstly, the aim of the first block was to collect data about respondents as well as their general characteristics. Due to the fact that the traineeship of simulation entrepreneurial development was aimed to improve students' knowledge gained while studying different subjects at the university, in the second block of questions students were asked to evaluate their gained knowledge of different study subjects (10 point scoring system). Also, respondents were asked to estimate the possibility to reach the full potential of their personalities during the traineeship. The other block of questions covered challenges, which prevented the reach of the full potential of students' entrepreneurial competences during the traineeship of simulation entrepreneurial development. During this traineeship various nontraditional methods were applied; thus, respondents were asked to estimate importance and efficiency of each method. The last block of questions asked respondents to estimate the change of knowledge, abilities and skills during the traineeship of simulation entrepreneurial development. In order to assess the change in the reach of full potential of personality, challenges, methods and measures, knowledge, abilities and skills, the scales were used, in which 6 - significant change/challenge, 1 - no change/challenge.

The general characteristic of respondents: during the spring semester of 2017,124 students participated in traineeship of simulation entrepreneurial development. 104 students participated in the research. Students participating in traineeship studied in different study programmes: Logistics and Commerce 
( $3^{\text {rd }}$ year), Administration of Rural Development ( $3^{\text {rd }}$ year), Management of Rural Development $\left(3^{\text {rd }}\right.$ year), Culture and Tourism Management ( $3^{\text {rd }}$ year), Applied Economics and Business Analysis ( ${ }^{\text {rd }}$ year), Accounting and Finance ( $4^{\text {th }}$ year). According to sex, respondents distributed as follows: $46.2 \%-$ men, $53.8 \%$ - women. While defining the profile of respondents, it is important to highlight that $79.8 \%$ of respondents has an experience as employees, 19.2\% of respondents has an experience in their own business and 30.8 percentage of respondents has intentions to develop their own business.

\section{Results and Discussion}

Presentation of the traineeship of simulation entrepreneurial development. Students of the Faculty of Economics and Management of Aleksandras Stulginskis University are participating in the traineeship of simulation entrepreneurial development. This is the obligatory subject for the final year students. The main principle of traineeship students participate in an intensive one-month course where they establish simulation business enterprise, elect a manager. 4 simulation business enterprises are established while organizing traineeship. Elected managers form their teams, which are composed of students studying different subjects. In each business, an enterprise activity is carried out in four departments: Department of Marketing and Sales Management, Accountancy and Finance management, Production and Procurement Management, Personnel Management. The main purpose of this traineeship is to improve gained specialist knowledge, promote students' awareness regarding entrepreneurship, develop students' management, technical and personal skills, develop students' entrepreneurial competences. In order to achieve this aim, simulations occur the enterprise is established and its produced goods or services have been sold. The course is intensive, employees of the enterprise attend the course daily as they would go to work and perform all planned tasks, in order to achieve the main goal of enterprise - to generate profit. Various entrepreneurial competences - from general to specific - are developed. During the traineeship students often have to leave their comfort zone and achieve their goals and this is the time when great changes occur and students understand the main goals of the traineeship. University teachers, who are specialists of finances, management and marketing, work with students during the traineeship. During the traineeship teachers play a role of consultants. They answer students' questions regarding business activity, mentor the implementation of the tasks and give the final evaluation. The agenda of the traineeship of simulation entrepreneurial development is composed while trying to consolidate students' gained knowledge and to help learn or consolidate entrepreneurial competences.

Presentation of research results. Respondents were asked to evaluate their knowledge gained during studying different subjects and which were necessary while performing tasks given during traineeship. The research results suggest that respondents evaluated themselves averagely. The evaluation is between 6 and 8 (10 point scoring system): management -7.8 , human resource management -7.7 , accounting -6.6 , finance management -6.8 , marketing -7.8 , business information systems -7.5 . Such research results occurred because the respondents part of subjects studied in early years; moreover, students of different programme studies separate subjects not at the same level. Thus, during the traineeship students had to search additional information, pay a lot of attention to studies on their own, because they feel a lack of some knowledge, specifically, in the fields of accounting, finance management, management of business information systems.

Not only knowledge, experience and motivation are important in business - certain moral, psychological preparation and personal characteristics

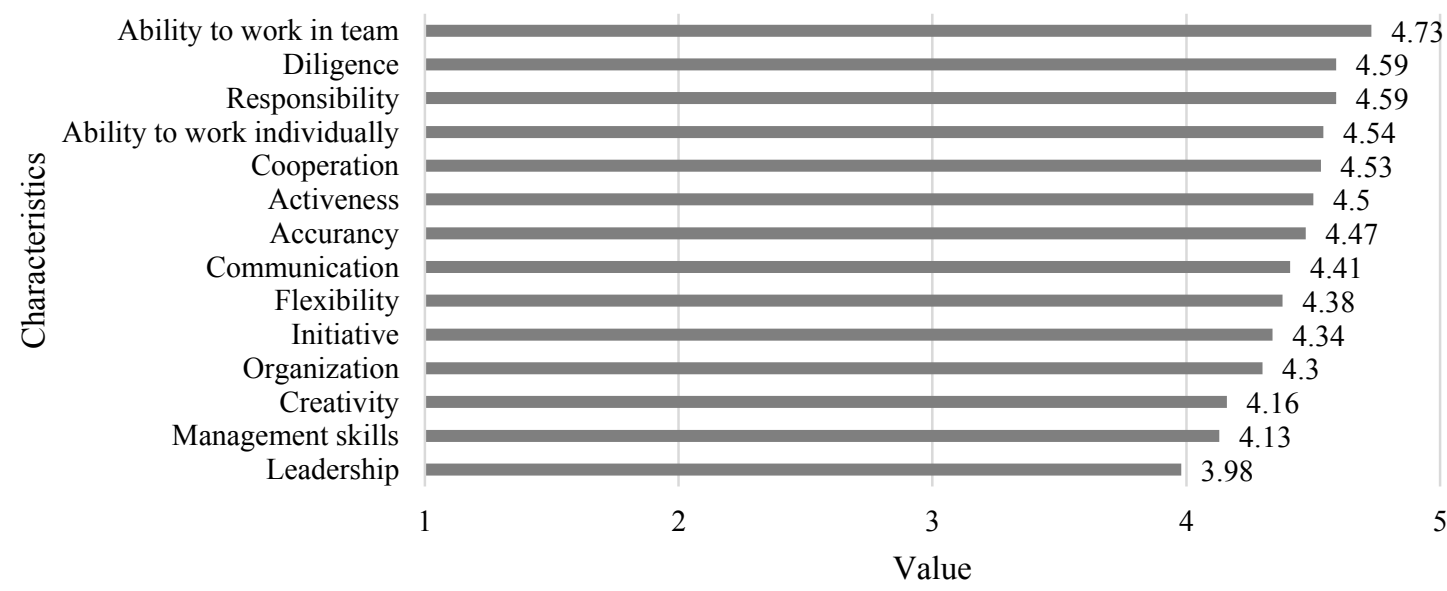

Figure 2. The growth of personal potential during traineeship of simulation entrepreneurial development. 


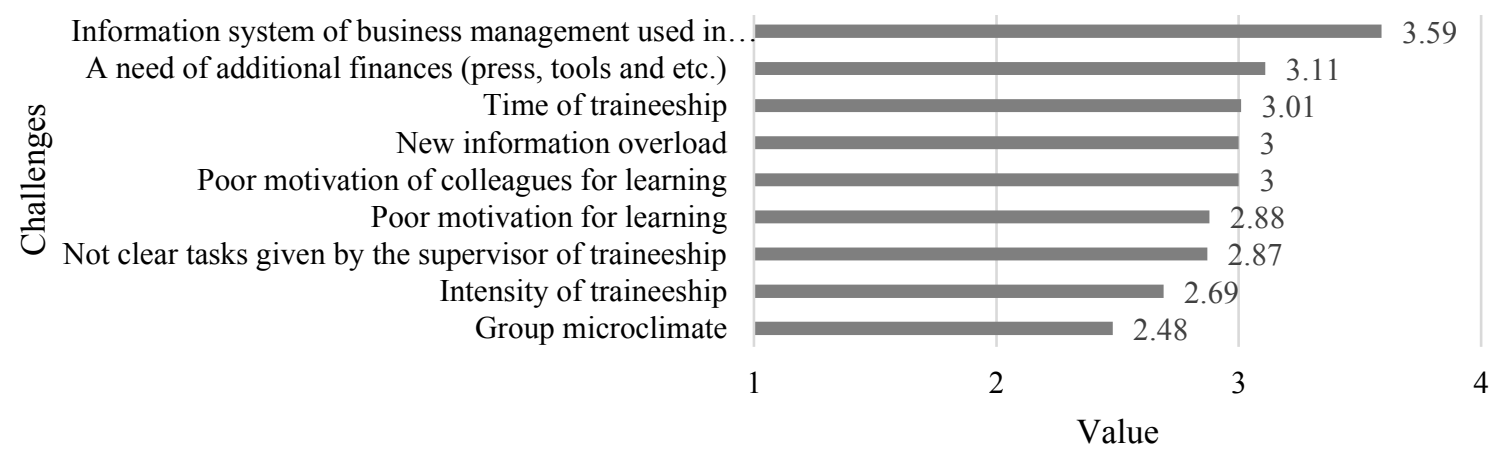

Figure 3. Challenges for the development of entrepreneurial competences during TDE.

play an important role as well. During traineeship of simulation entrepreneurial development every student has an opportunity to choose what kind of position - a manager or specialist they would like to have. $38.6 \%$ percentage of respondents took part as managers, $61.5 \%$ percentage of respondents became specialists. Students willing to become managers were the minority. On the other hand, not all students expressed a wish to be managers were appointed to these positions. These decisions were made by other students, because they knew each other better during study years.

During research respondents were asked to estimate the change in the reach of full potential of their personality (evaluation scoring scale: 6 - full potential, 1 - no potential).

According to the respondents, such a personal quality as ability to work in a team was displayed on a high level (4.73 - displayed). The majority of tasks were oriented towards teamwork. From the research results it can be concluded that students studying different subjects and having different experience are able to achieve coherently planned goals, search common solutions and solve problems and conflicts. Diligence (4.59 - displayed) and responsibility (4.59 - displayed) were valued a little lower. These personal qualities were developed via the intensity of the traineeship (the duration is one month, 4 hours every day). During the traineeship respondents have to behave responsibly, to perform their duties and tasks, to come to work on time. Various disciplinaries (during the simulation traineeship students develop and implement the system of motivational measures by themselves) were applied to those, who were late to work and did not perform tasks in time. According to the respondents, these qualities developed during the traineeship.

Also, the amount of applied methods to the traineeship makes this traineeship of entrepreneurial development more intensive. Respondents were asked to evaluate the main challenges, which prevented the growth of personal qualities and acquisition and development of entrepreneurial competences. As the biggest challenge the respondents identified information system for business management (3.59-displayed). During the studies only students of accounting and finances are familiar with IT programs for enterprise management. As a result, the usage of this program becomes an obstacle for students from other programs. Students spend a considerable amount of time while analyzing the main principles of this system while performing tasks. A need of additional finances, time of traineeship respondents identified as big challenges; however, these challenges were very important for the development of such entrepreneurial competences as time planning (a part of students worked as employees), stress management, creativity, rationality, ecological behavior (tried to work with limited resources), etc. In conclusion, it can be stated that teamwork and formed teams were able to create

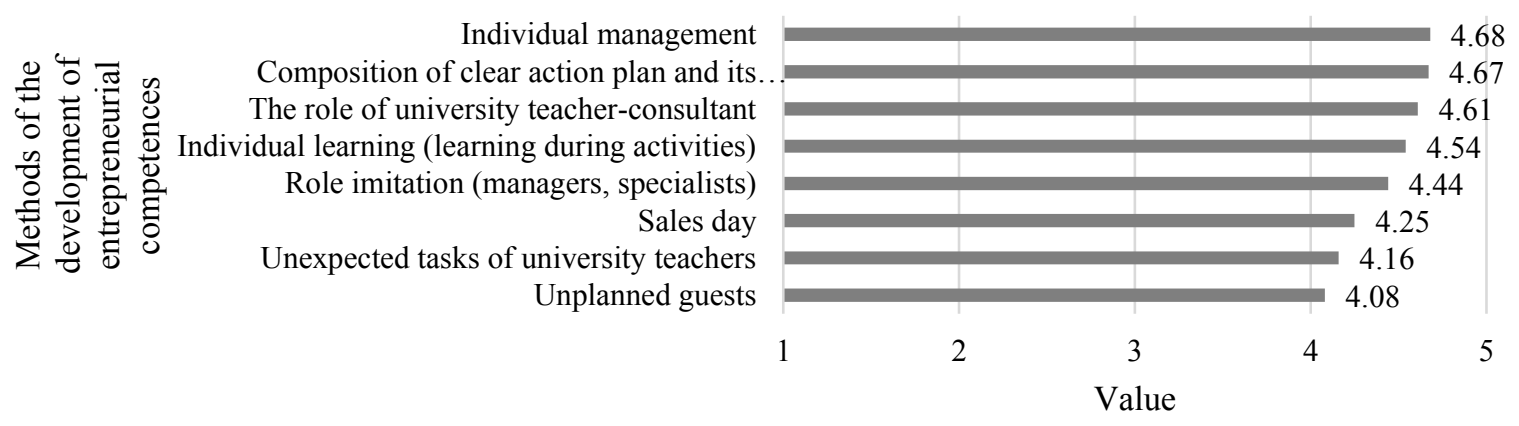

Figure 4. Methods of the development of entrepreneurial competences applied in traineeship. 


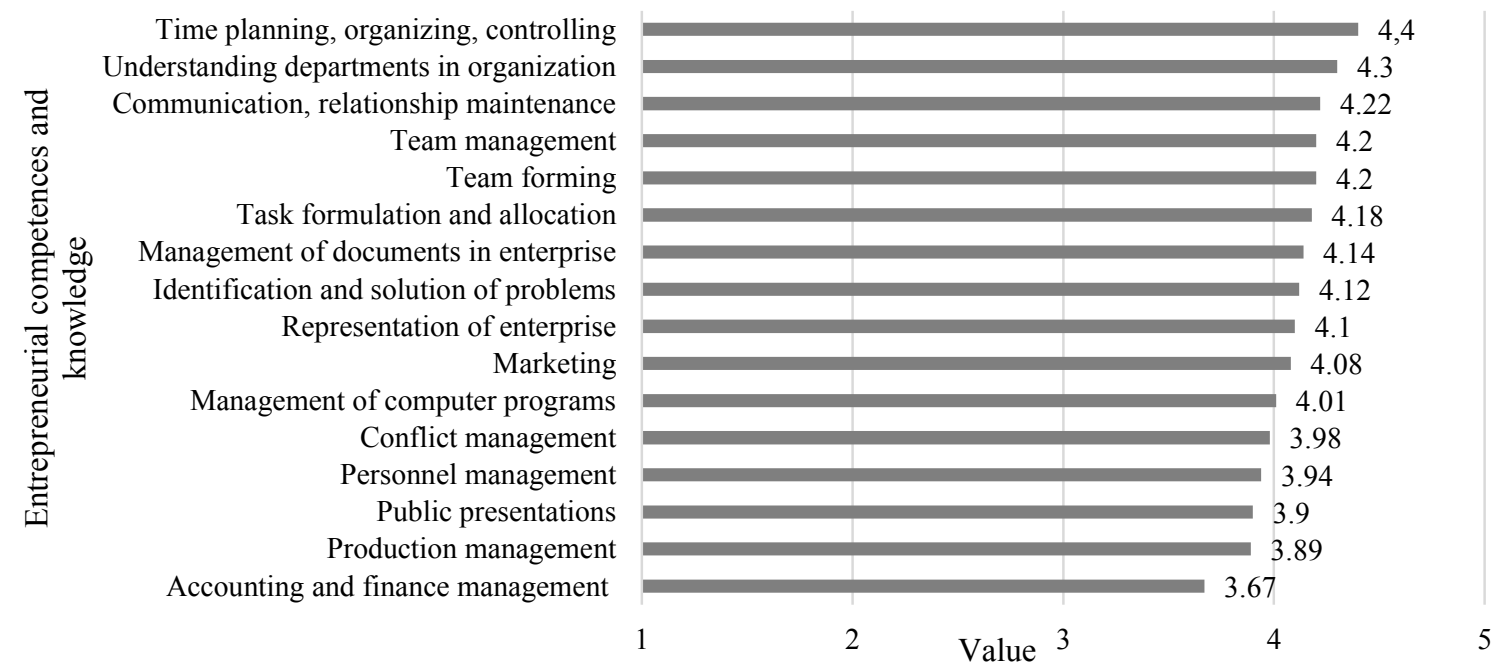

Figure 5. The change in the entrepreneurial competences and knowledge during traineeship.

a positive microclimate within the group and solve problems with competences and resources of the group.

Various innovative methods directed to the development of students' entrepreneurial competences were applied in traineeship of the entrepreneurial development. A lot of attention was paid to students' individualities during traineeship in enterprise management and decision making; therefore, individual management $(4.68$ - displayed) respondents identified as a very important method. During the practice a task was formulated that students' simulation business enterprise would operate according to their developed activity plan for the whole period. The research results show that respondents evaluate it as a very important method. During the traineeship of entrepreneurial development, university teachers do not play their traditional role. In this case, the university teacher plays a role of consultant - he provides recommendations, helps to formulate possible alternatives to the solution; however, all decisions are made by the students themselves. According to the research, this role of a teacher - consultant (4.61 displayed) is quite an important educational method. During the research the following 8 methods from 17 were identified by the students as the most important and have the greatest impact.

Methods applied in traineeship of simulation entrepreneurial development and the structure of this traineeship allows to improvise, to display personal qualities in various innovative ways and to develop students' entrepreneurial competences. In the last block of questions students were asked to estimate the change in their entrepreneurial competences during the traineeship of simulation entrepreneurial development. According to the respondents, such competences as activity planning, organization and control more changed than remained unchanged
(4.4 - displayed). Also, the big part of respondents stated that their awareness regarding connections between the departments in organization was improved during this intensive traineeship (4.3 - displayed). Due to the fact that the main attention was paid to form a team having a common purpose, respondents stated that the competence of communication and relation maintenance has changed (4.22 - displayed). However, the smallest change occurred in the area of accounting and finance management (3.67 displayed). Such research results were caused by the fact that quite a small part $(15 \%)$ of students participating in the traineeship studied accounting and finances. Students of other programs have only basic knowledge regarding accounting and finance and their knowledge is not very deep in this area. Another reason -business management system was used during the traineeship, and this system was not clear to all students.

Research results cover acquisition of entrepreneurial competences during traineeship of entrepreneurial development in both ways: qualitative and quantitative. The general tendencies revealed that the model of traineeship of entrepreneurial development, which operates as a simulation enterprise, contributes to the development of students' entrepreneurial competences. A survey lets to identify a problematic area of this traineeship, possibly less effective methods for the development of entrepreneurial competences and search possibilities to improve this area.

After taking into consideration the carried out research, it can be stated that there is a need of a set of systematic and structural methods, which would develop entrepreneurial competences. In this area, it shall be recommended to complement methodology, specifying tasks and identifying portfolio of entrepreneurial competences as a purpose of every 
student in the traineeship. The main improvements could be directed to the model of entrepreneurial competences development while using the creation of simulation via four dimensions: creative thinking, graphic thinking, provocation creative technique and resultative thinking.

\section{Conclusions}

In the development of students' entrepreneurship, it is important to promote their entrepreneurial motivation and development of their personal competences. Every student is an individual, who has different work experience, knowledge and motivation. This actualizes application of various methods promoting students' creativity in the process of the development of entrepreneurial competences.
The research results show that entrepreneurial competences developed during the traineeship of entrepreneurial competences; the development was positive, and applied methods were evaluated as quite effective. However, it can be stated that there is a need for a common system and the action plan of traineeship of entrepreneurial development, the precise introduction of each method and an application system. Several identified methods compose only one part of all possible innovative methods; however, they also have to be selected and applied in quite an accurate manner. However, while evaluating entrepreneurial competences, it becomes obvious that respondents tend to evaluate positively personal qualities and they understand and analyze their entrepreneurial competences.

\section{References}

1. Buzys, A. (2016). Kūrybiškas mąstymas. 99 pratimai ir technikos norintiems mąstyti bei veikti kūrybiškai (Creative thinking. 99 exercises and technicians who want to think and act creatively), 34-40, (in Lithuanian).

2. Donnellon, A., Ollila, S., \& Middleton, K.W. (2014). Constructing entrepreneurial identity in entrepreneurship education. The International Journal of Management Education, 12, 490-499. DOI: 10.1016/j.ijme.2014.05.004.

3. Driessen, M.P., \& Zwart, P.S. (1999). The Entrepreneur Scan Measuring Characteristics and Traits of Entrepreneurs. Retrieved March 16, 2018, from: https://entrepreneurscan.com//wp-content/ uploads/2016/09/E-Scan-MAB-Article-UK.pdf.

4. Estrin, S., Mickiewicz, T., \& Stephan, U. (2016). Human capital in social and commercial entrepreneurship. Journal of Business Venturing. 31, 449-467. DOI: 10.1016/j.jbusvent.2016.05.003.

5. Guardia, La.D., Gentile, M., Grande, D.V., Ottaviano, S., \& Allegra, M. (2014). A Game Based Learning Model for Entrepreneurship Education. Institute for Educational Technology - National Research Council of Italy Via U. La Malfa n. 153, 90146 Palermo - Italy, DOI: 10.1016/j.sbspro.2014.05.034.

6. Hayden, J.K., Smiley, R.A., Alexander, M., Kardong-Edgren, S., \& Jeffries, P. (2014). The NCSBN national simulation study: A longitudinal randomized, controlled study replacing clinical hours with simulation in prelicensure nursing education. Journal of Nursing Regulation, 5(2), S3-S64, DOI: 10.1016/S21558256(15)30062-4.

7. Ismail, V.Y., Zain, E., \& Zulihar, E. (2015). The Portrait of Entrepreneurial Competence on Student Entrepreneurs. The 6th Indonesia International Conference on Innovation, Entrepreneurship and Small Business, DOI: 10.1016/j.sbspro.2015.01.300.

8. Jansen, S., van de Zande, T., Brinkkemper, S., Stam, E., \& Varma, V. (2015). How education, stimulation, and incubation encourage student entrepreneurship: Observations from MIT, IIIT, and Utrecht University. The International Journal of Management Education. 13, 170-181. DOI: 10.1016/j.ijme.2015.03.001.

9. Kardelis, K. (2016). Moksliniu tyrimu metodologija ir metodai. (Research methodology and methods). Mokslo ir enciklopedijų leidybos centras, Vilnius (in Lithuanian).

10. Kyndt, E., \& Baert, H. (2015). Entrepreneurial competencies: Assessment and predictive value for entrepreneurship. Journal of Vocational Behavior. 90, 13-25. DOI: 10.1016/j.jvb.2015.07.002.

11. Lans, T., Blok, V., \& Wesselink, R. (2014). Learning apart and together: towards an integrated competence framework for sustainable entrepreneurship in higher education. Journal of Cleaner Production. 62, 3747. DOI: $10.1016 /$ j.jclepro.2013.03.036.

12. Misiukonis, T., Matusevičiūtè, V., Grajauskas, M. (2015). Attention group! Practical work with a group of methods and techniques. Vilnius: Vaga.

13. Mueller, S., \& Anderson, A.R. (2014). Understanding the entrepreneurial learning process and its impact on students' personal development: A European perspective. The International Journal of Management Education. 12, 500-511. DOI: 10.1016/j.ijme.2014.05.003.

14. Robles, R., \& Zárraga-Rodríguez, M. (2015). Key Competencies for Entrepreneurship. Retrieved March 1, 2018, from: https://www.researchgate.net/publication/282555235_Key_Competencies_for_ Entrepreneurship. 
15. Schachter, M.E., García-Granero, A., Sánchez-Barrioluengo, M., Quesada-Pineda, H., \& Amara, N. (2015). Disentangling competences: Interrelationships on creativity, innovation and entrepreneurship. Retrieved March 16, 2018, from: http://daneshyari.com/article/preview/375560.pdf.

16. Schelfhout, W., Bruggeman, K., \& De Maeyer, S. (2016). Evaluation of entrepreneurial competence through scaled behavioural indicators: Validation of an instrument. Studies in Educational Evaluation. 51, 29-41. DOI: 10.1016/j.stueduc.2016.09.001.

17. Shin, H., Sok, S., Hyun, K.S., \& Kim, M.J. (2015). Competency and an active learning program in undergraduate nursing education. Journal of Advanced Nursing, 71(3), 591-598, DOI: 10.1111/jan.12564.

18. Stamboulis, Y., \& Barlas, A. (2014). Entrepreneurship education impact on student attitudes. The International Journal of Management Education. 12, 365-373. DOI: 10.1016/j.ijme.2014.07.001.

19. Strazdienè, G., \& Garalis, A. (2006). Verslumas: ugdymo programos ir jų efektyvumo raiška. (Entrepreneurship: educational programs and their effectiveness). Organizaciju vadyba: sisteminiai tyrimai. 38, 153-167. (in Lithuanian).

20. Walters, B., Potetz, J., \& Fedesco, H.N. (2017). Simulations in the classroom: an innovative active learning experience. Clinical Simulation in Nursing, 13(12), 609-615. DOI: 10.1016/j.ecns.2017.07.009.

21. Žydžiūnaitè, V., \& Sabaliauskas, S. (2017). Kokybiniai tyrimai principai ir metodai (Qualitative research principles and methods). Vilnius: Vaga, (in Lithuanian). 